\title{
MULTIVARIATE ANALYSIS OF CHEMICAL AND PHYSICAL ATTRIBUTES OF QUARTZIPSAMMENTS UNDER DIFFERENT AGRICULTURAL USES
}

\author{
Sálvio N. S. Arcoverde ${ }^{1}$, Jorge W. Cortez ${ }^{2}$, Nelci Olszevski ${ }^{3}$, Alessandra M. Salviano ${ }^{4}$, \\ Vanderlise Giongo ${ }^{4}$
}

${ }^{1 *}$ Corresponding author. Federal University of Grande Dourados/ Dourados - MS, Brasil.

E-mail: salvionapoleao@gmail.com | ORCID ID: https://orcid.org/0000-0002-0453-4566

\section{KEYWORDS}

principal component, quality indicator, soil quality, sandy soils.

\begin{abstract}
The inadequate agricultural management in the semiarid region of northeastern Brazil, associated with the fragility of most soils, has caused degradation of the quality of this resource. This study aimed to evaluate the quality of Quartzipsamments under different uses through the multivariate analysis of chemical and physical attributes. Five areas were selected: four of them with agricultural use (onion, banana, cassava, and corn) and the other with Caatinga. Soil samples were collected at depths of $0.00-0.10,0.10-0.20$, and $0.20-0.40 \mathrm{~m}$ for chemical and physical analyses. The data were submitted to descriptive analysis and then to the multivariate analysis using the principal component analysis (PCA) technique and Ward's clustering method. PCA and clustering techniques allowed the identification of different production systems in subsurface layers, suggesting the effect of fertility on the differentiation of areas with onion and banana, as well as the clustering of cassava and corn cultivations. Physical attributes and sodium content of the surface layer of the area with onion showed a tendency of compaction and salinization process of this environment. In general, fertility was the main responsible for the improvement of soil quality with agricultural use when compared to the Caatinga.
\end{abstract}

\section{INTRODUCTION}

The implementation of agricultural exploitation systems may cause negative impacts on the soil due to the adoption of a model of agriculture that does not prioritize the rational use of natural resources. The occupation of soils considered of low aptitude without the previous assessment of their use capacity can lead to the adoption of inadequate management systems and their degradation, especially when fragile soils, such as sandy soils, are inserted into the productive process (Sales et al., 2010; Mota \& Valladares, 2011). However, the agricultural use of Quartzipsamments is common in the semiarid region of northeastern Brazil. According to Jacomine (1996), this soil class covers around $9.3 \%$ of the area of the region.

Although there is information on soils from the semiarid region, such as exploratory surveys and other studies of this theme (Jacomine, 1996; Santos et al., 2012), it is always valid to carry out studies on the characterization of different representative soils on a more detailed scale (Mota \& Valladares, 2011). Soil characterization studies in regions little explored allows providing more accurate information on the different soil classes throughout the Brazilian territory, as well as systematizing this information on soil properties, which may be a subsidy for the development of management practices, sustainable use, and recovery of degraded areas (Santos et al., 2012).

The detailing of potentialities and fragilities is of extreme importance to the planning to minimize impacts observed continuously in the region (Corrêa et al., 2010). These impacts are considered the result of a combination of agriculture management and environmental characteristics (Corrêa et al., 2010; Mota \& Valladares, 2011; Ursulino \& Moreno, 2014), which together lead to and accelerate the development of physical and chemical degradation. These processes are mainly due to the use of irrigation systems (furrows and flooding) of low efficiency, overuse of chemical fertilizers, and, in many cases, unfavorable natural drainage conditions. These factors, coupled with the high evapotranspiration demand and low rainfall index (Corrêa et al., 2010),

\footnotetext{
${ }^{2}$ Universidade Federal da Grande Dourados/ Dourados - MS, Brasil.

${ }^{3}$ Universidade Federal do Vale do São Francisco/ Juazeiro - BA, Brasil.

${ }^{4}$ Empresa Brasileira de Pesquisa Agropecuária - Embrapa Semiárido/ Petrolina - PE, Brasil.

Received in: 8-18-2016

Accepted in: 6-3-2019
} 
have accelerated the salinization process of these areas, negatively affecting changes in physical and chemical attributes.

Thus, it is necessary to carry out studies to better understand changes caused by soil use, aiming at maximizing production and avoiding the degradation of agricultural soils since they generate essential information for the management and conservation of tropical sandy soils incorporated into intensive productive processes (Sales et al., 2010). In this sense, according to Corrêa et al. (2010), changes in soil attributes can be observed after agricultural use and agricultural uses can be compared. Also, sustainability can be evaluated from use evaluations with soil attributes as indicators, aiming at the evaluation of productive systems to adapt systems or propose more sustainable uses.

In this context, the multivariate analysis technique can be used as a tool to explain the maximum correlation between soil characteristics and indicate those that most contribute to soil characterization and/or soil alteration (Freitas et al., 2014; Oliveira et al., 2015). Several studies have applied the multivariate technique for soil quality analysis (Pragana et al., 2012; Freitas et al., 2014; Arcoverde et al., 2015; Oliveira et al., 2015).

Therefore, this study aimed to evaluate the quality of Quartzipsamments under different uses through the multivariate analysis of chemical and physical attributes.

\section{MATERIAL AND METHODS}

The studied Quartzipsamments are located in the municipalities of Casa Nova, Remanso, and Sento Sé, on the banks of Sobradinho Lake in the state of Bahia. According to Köppen classification, the climate BSwh' (warm and semiarid) predominates in $75 \%$ of the area, with annual precipitation varying from 500 to $900 \mathrm{~mm}$; the arid climate can be found in the other $25 \%$ of the area, with annual precipitation lower than $500 \mathrm{~mm}$. The predominant vegetation is the hyperxerophilic Caatinga. The surroundings of the Sobradinho Lake is characterized by intense agricultural activity, standing out the irrigated agriculture and vegetable cultivation, mainly onion.

Five areas with soils classified as Quartzipsamment, located on the banks of the lake and under different uses, were used in this study: a) onion cultivation $(\mathrm{O}), \mathrm{b})$ banana cultivation $(\mathrm{B}), \mathrm{c}$ ) cassava (CA), d) corn cultivation (CO), and e) Caatinga (CAA) (Table 1). Soil tillage for planting in the areas with agricultural use was performed with a disc plow and heavy disc harrow; liming and fertilization was also carried out in the areas.

TABLE 1. Municipalities, geographical coordinates, and use of Quartzipsamments.

\begin{tabular}{ccc}
\hline Longitude & Latitude & Soil use \\
\hline \multicolumn{2}{c}{ Casa Nova } & \\
262929 & 8968752 & Onion (O) \\
194314 & 8935964 & Banana (B) \\
\multicolumn{2}{c}{ Remanso } & Cassava (CA) \\
816948 & 8934491 & Corn (CO) \\
170918 & 8935889 & \\
234119 & 8917500 & Caatinga (CAA) \\
\hline
\end{tabular}

The five areas presented Quartzipsamments with a textural class predominantly loamy sandy at depths of $0.00-10,0.10-0.20$, and $0.20-0.40 \mathrm{~m}$, whose mean particle size is shown in Table 2.

TABLE 2. Particle size composition of Quartzipsamments by depth.

\begin{tabular}{cccc}
\hline \multirow{2}{*}{ Depth $(\mathrm{m})$} & \multicolumn{3}{c}{ Particle size $\left(\mathrm{g} \mathrm{kg}^{-1}\right)$} \\
\cline { 2 - 4 } & Sand & Silt & Clay \\
\hline $0.00-0.10$ & 883 & 27 & 90 \\
$0.10-0.20$ & 880 & 24 & 96 \\
$0.20-0.40$ & 863 & 30 & 107 \\
\hline
\end{tabular}

Disturbed and undisturbed soil samples were collected at depths of $0.00-0.10,0.10-0.20$, and $0.20-0.40$ $\mathrm{m}$. Each area was divided into three sub-areas of sampling to collect ten simple disturbed soil samples, which composed a composite sample, totaling three composite samples per depth and sub-area. Trenches were opened in the middle of each sub-area to collect undisturbed soil samples.

Soil physical analyses included soil bulk density (Ds), analyzed by the beaker method, particle size according to Donagema et al. (2011), and soil macroporosity (Ma) and microporosity (Mi) were estimated by the mathematical model proposed by Stolf et al. (2011) based on the following equations: $\mathrm{Ma}=0.693-$ $0.465 \times \mathrm{Ds}+0.212 \times$ Sand and $\mathrm{Mi}=0.337+0.120 \times \mathrm{Ds}-$ $0.294 \times$ Sand.

Soil chemical analyses were carried out according to Donagema et al. (2011) and included: (i) $\mathrm{pH}$ in water (soil:liquid ratio of $1: 2.5)$; (ii) assimilable phosphorus, extracted by Mehlich-1 $\left(0.05 \mathrm{~mol} \mathrm{~L}^{-1} \mathrm{HCl}\right.$ and $0.0125 \mathrm{~mol}$ $\mathrm{L}^{-1} \mathrm{H}_{2} \mathrm{SO}_{4}$ ) and determined in a photocolorimeter in the presence of ascorbic acid; (iii) exchangeable cations $\left(\mathrm{Ca}^{2+}\right.$, $\mathrm{Mg}^{2+}, \mathrm{Na}^{+}$, and $\mathrm{K}^{+}$), being $\mathrm{Ca}^{2+}$ and $\mathrm{Mg}^{2+}$ extracted by 1 mol $\mathrm{L}^{-1} \mathrm{KCl}$ and determined by volumetric complexation with 0.0125 mol L${ }^{-1}$ EDTA solution, and $\mathrm{Na}^{+}$and $\mathrm{K}^{+}$ extracted by the Mehlich-1 extractor $\left(0.05 \mathrm{~mol} \mathrm{~L}^{-1} \mathrm{HCl}\right.$ and $0.0125 \mathrm{~mol} \mathrm{~L}^{-1} \mathrm{H}_{2} \mathrm{SO}_{4}$ ) and determined by flame photometry; (iv) aluminum content, extracted with $1 \mathrm{~mol}$ $\mathrm{L}^{-1} \mathrm{KCl}$ solution and determined by volumetric neutralization with $0.0251 \mathrm{~mol} \mathrm{~L}^{-1} \mathrm{NaOH}$; (v) potential acidity $(\mathrm{H}+\mathrm{Al})$ extracted with calcium acetate buffered to $\mathrm{pH} 7.0$; (vi) organic carbon, determined by the WalkleyBlack method; (vii) electrical conductivity in the saturation extract, determined using a conductivity meter; and (viii) available copper, iron, manganese, and zinc contents, extracted with Mehlich-1 $\left(0.05 \mathrm{~mol} \mathrm{~L}^{-1} \mathrm{HCl}\right.$ and 0.0125 mol $\mathrm{L}^{-1} \quad \mathrm{H}_{2} \mathrm{SO}_{4}$ ) and determined by flame atomic absorption spectrophotometry.

The mean and standard deviation were calculated by the classical statistics for each studied attribute. The multivariate technique was used through the principal component analysis (PCA) and hierarchical cluster analysis.

PCA was performed aiming at reducing a large number of variables into a more significant set (represented by principal components), identifying the variables belonging to the components, and determining how much each variable explains each component to evidence attributes associated with the changes in the areas (Freitas et al., 2014). The minimum of principal 
components with at least $70 \%$ of the total data variance was adopted (Burak et al., 2012). Also, the principal components were those with a value of a correlation coefficient between the principal component and the variable above 0.65 in absolute value, as described in Arcoverde et al. (2015).

The hierarchical cluster analysis was performed by calculating the Euclidean distance between the accessions for the set of 12 attributes using Ward's algorithm to obtain clusters of similar accessions. This analysis was used to verify the similarities between analyzed attributes and studied areas from homogeneous clusters represented in a similarity dendrogram.

\section{RESULTS AND DISCUSSION}

The agricultural uses promoted modifications in the mean values of the physical and chemical attributes of Quartzipsamments at the three studied depths (Table 3).

TABLE 3. Chemical and physical characterization of Quartzipsamments under different uses at depths of $0.00-0.10,0.10$ 0.20 , and $0.20-0.40 \mathrm{~m}$.

\begin{tabular}{|c|c|c|c|c|c|c|}
\hline \multirow{3}{*}{ Attribute } & \multirow{3}{*}{ Unit } & \multicolumn{5}{|c|}{ Soil use } \\
\hline & & Onion & Banana & Cassava & Corn & Caatinga \\
\hline & & \multicolumn{5}{|c|}{$0.00-0.10 \mathrm{~m}$} \\
\hline Ds & $\mathrm{Mg} \mathrm{m}^{-3}$ & $1.60 \pm 0.02$ & $1.51 \pm 0.09$ & $1.45 \pm 0.01$ & $1.51 \pm 0.04$ & $1.73 \pm 0.01$ \\
\hline $\mathrm{Ma}$ & $\mathrm{m}^{3} \mathrm{~m}^{-3}$ & $0.10 \pm 0.01$ & $0.14 \pm 0.03$ & $0.18 \pm 0.00$ & $0.11 \pm 0.01$ & $0.17 \pm 0.04$ \\
\hline $\mathrm{Mi}$ & $\mathrm{m}^{3} \mathrm{~m}^{-3}$ & $0.26 \pm 0.00$ & $0.26 \pm 0.00$ & $0.24 \pm 0.00$ & $0.26 \pm 0.01$ & $0.25 \pm 0.01$ \\
\hline $\mathrm{OM}$ & dag $\mathrm{kg}^{-1}$ & $9.72 \pm 4.93$ & $3.31 \pm 1.39$ & $2.38 \pm 0.31$ & $2.69 \pm 0.27$ & $18.45 \pm 7.12$ \\
\hline $\mathrm{pH}$ & - & $6.86 \pm 1.57$ & $6.0 \pm 0.4$ & $4.74 \pm 0.02$ & $4.93 \pm 0.15$ & $7.29 \pm 0.15$ \\
\hline $\mathrm{P}$ & $\mathrm{mg} \mathrm{dm}^{-3}$ & $4.94 \pm 2.35$ & $4.79 \pm 1.70$ & $2.85 \pm 0.27$ & $6.97 \pm 0.86$ & $5.70 \pm 1.85$ \\
\hline $\mathrm{Mg}$ & & $1.60 \pm 0.61$ & $0.32 \pm 0.09$ & $0.16 \pm 0.04$ & $0.34 \pm 0.10$ & $0.80 \pm 0.10$ \\
\hline $\mathrm{Ca}$ & & $7.53 \pm 0.31$ & $0.67 \pm 0.38$ & $0.42 \pm 0.03$ & $0.78 \pm 0.21$ & $4.47 \pm 0.40$ \\
\hline $\mathrm{K}$ & cmolc $\mathrm{dm}^{-3}$ & $0.55 \pm 0.22$ & $0.17 \pm 0.08$ & $0.12 \pm 0.03$ & $0.12 \pm 0.04$ & $0.31 \pm 0.05$ \\
\hline $\mathrm{Na}$ & & $0.09 \pm 0.02$ & $0.03 \pm 0.01$ & $0.00 \pm 0.01$ & $0.01 \pm 0.00$ & $0.04 \pm 0.00$ \\
\hline $\mathrm{H}+\mathrm{Al}$ & & $4.16 \pm 0.83$ & $3.15 \pm 0.88$ & $4.37 \pm 0.46$ & $4.48 \pm 1.73$ & $2.35 \pm 0.46$ \\
\hline \multirow{2}{*}{$\mathrm{CEC}_{\text {eff }}$} & & $9.82 \pm 0.17$ & $1.45 \pm 0.43$ & $1.23 \pm 0.13$ & $1.49 \pm 0.18$ & $5.67 \pm 0.48$ \\
\hline & \multicolumn{6}{|c|}{$0.10-0.20 \mathrm{~m}$} \\
\hline$\overline{\mathrm{Ds}}$ & $\mathrm{Mg} \mathrm{m}^{-3}$ & $1.61 \pm 0.01$ & $1.50 \pm 0.06$ & $1.50 \pm 0.02$ & $1.49 \pm 0.02$ & $1.75 \pm 0.00$ \\
\hline Ma & $\mathrm{m}^{3} \mathrm{~m}^{-3}$ & $0.09 \pm 0.01$ & $0.14 \pm 0.02$ & $0.15 \pm 0.00$ & $0.13 \pm 0.01$ & $0.16 \pm 0.01$ \\
\hline Mi & $\mathrm{m}^{3} \mathrm{~m}^{-3}$ & $0.26 \pm 0.00$ & $0.26 \pm 0.00$ & $0.24 \pm 0.00$ & $0.27 \pm 0.01$ & $0.24 \pm 0.00$ \\
\hline $\mathrm{OM}$ & dag $\mathrm{kg}^{-1}$ & $7.14 \pm 0.52$ & $8.65 \pm 6.06$ & $1.48 \pm 0.61$ & $3.90 \pm 0.84$ & $8.00 \pm 1.1$ \\
\hline $\mathrm{pH}$ & - & $6.45 \pm 0.67$ & $5.37 \pm 0.26$ & $5.93 \pm 0.15$ & $4.52 \pm 0.05$ & $6.88 \pm 0.35$ \\
\hline $\mathrm{P}$ & $\mathrm{mg} \mathrm{dm}^{-3}$ & $187.8 \pm 101.4$ & $74.78 \pm 62.9$ & $3.47 \pm 1.15$ & $7.80 \pm 0.97$ & $19.22 \pm 14.45$ \\
\hline $\mathrm{Mg}$ & & $0.97 \pm 0.06$ & $0.6 \pm 0.2$ & $0.52 \pm 0.07$ & $0.33 \pm 0.13$ & $0.53 \pm 0.15$ \\
\hline $\mathrm{Ca}$ & & $7.77 \pm 1.55$ & $2.7 \pm 0.82$ & $1.04 \pm 0.14$ & $0.51 \pm 0.08$ & $2.67 \pm 0.40$ \\
\hline $\mathrm{K}$ & cmolc $\mathrm{dm}^{-3}$ & $0.90 \pm 0.00$ & $0.33 \pm 0.14$ & $0.06 \pm 0.02$ & $0.14 \pm 0.01$ & $0.36 \pm 0.10$ \\
\hline $\mathrm{Na}$ & & $0.08 \pm 0.01$ & $0.05 \pm 0.02$ & $0.01 \pm 0.00$ & $0.01 \pm 0.00$ & $0.04 \pm 0.01$ \\
\hline $\mathrm{H}+\mathrm{Al}$ & & $3.50 \pm 0.00$ & $3.47 \pm 2.01$ & $2.77 \pm 0.46$ & $4.11 \pm 0.46$ & $2.10 \pm 0.00$ \\
\hline \multirow[t]{2}{*}{$\mathrm{CEC}_{\text {eff }}$} & & $9.76 \pm 1.60$ & $3.81 \pm 0.76$ & $1.69 \pm 0.21$ & $1.34 \pm 0.23$ & $3.68 \pm 0.56$ \\
\hline & \multicolumn{6}{|c|}{$0.20-0.40 \mathrm{~m}$} \\
\hline Ds & $\mathrm{Mg} \mathrm{m}^{-3}$ & $1.62 \pm 0.03$ & $1.48 \pm 0.04$ & $1.49 \pm 0.02$ & $1.47 \pm 0.01$ & $1.62 \pm 0.14$ \\
\hline Ma & $\mathrm{m}^{3} \mathrm{~m}^{-3}$ & $0.09 \pm 0.01$ & $0.16 \pm 0.02$ & $0.17 \pm 0.00$ & $0.14 \pm 0.02$ & $0.10 \pm 0.01$ \\
\hline $\mathrm{Mi}$ & $\mathrm{m}^{3} \mathrm{~m}^{-3}$ & $0.27 \pm 0.00$ & $0.26 \pm 0.01$ & $0.24 \pm 0.00$ & $0.27 \pm 0.01$ & $0.27 \pm 0.00$ \\
\hline $\mathrm{OM}$ & dag $\mathrm{kg}^{-1}$ & $1.66 \pm 0.81$ & $8.65 \pm 6.06$ & $1.07 \pm 0.06$ & $6.10 \pm 1.60$ & $4.59 \pm 1.04$ \\
\hline $\mathrm{pH}$ & - & $6.19 \pm 0.67$ & $5.41 \pm 0.89$ & $5.91 \pm 0.13$ & $5.83 \pm 0.12$ & $5.19 \pm 0.20$ \\
\hline $\mathrm{P}$ & $\mathrm{mg} \mathrm{dm} \mathrm{m}^{-3}$ & $2.13 \pm 0.17$ & $74.78 \pm 62.91$ & $2.75 \pm 0.76$ & $8.83 \pm 1.85$ & $3.14 \pm 0.65$ \\
\hline $\mathrm{Mg}$ & \multirow{6}{*}{ cmolc dm $\mathrm{dm}^{-3}$} & $0.22 \pm 0.04$ & $0.60 \pm 0.20$ & $0.49 \pm 0.11$ & $0.93 \pm 0.15$ & $0.09 \pm 0.04$ \\
\hline $\mathrm{Ca}$ & & $0.47 \pm 0.11$ & $2.70 \pm 0.82$ & $0.95 \pm 0.14$ & $2.03 \pm 0.15$ & $0.53 \pm 0.00$ \\
\hline $\mathrm{K}$ & & $0.12 \pm 0.66$ & $0.33 \pm 0.14$ & $0.09 \pm 0.05$ & $0.08 \pm 0.01$ & $0.09 \pm 0.01$ \\
\hline $\mathrm{Na}$ & & $0.02 \pm 1.01$ & $0.05 \pm 0.02$ & $0.01 \pm 0.00$ & $0.01 \pm 0.00$ & $0.02 \pm 0.00$ \\
\hline $\mathrm{H}+\mathrm{Al}$ & & $3.47 \pm 1.22$ & $3.47 \pm 2.01$ & $2.77 \pm 1.22$ & $3.31 \pm 0.46$ & $3.95 \pm 0.46$ \\
\hline $\mathrm{CEC}_{\text {eff }}$ & & $1.42 \pm 0.27$ & $3.81 \pm 0.76$ & $1.58 \pm 0.29$ & $3.11 \pm 0.06$ & $1.09 \pm 0.15$ \\
\hline
\end{tabular}

Ds: soil density; Ma: macroporosity; Mi: microporosity; OM: organic matter; P: assimilable phosphorus; Mg: exchangeable magnesium; Ca: exchangeable calcium; $\mathrm{K}=$ exchangeable potassium; Na: exchangeable sodium; $\mathrm{H}+\mathrm{Al}$ : potential acidity; $\mathrm{CEC}_{\text {eff: }}$ effective cation exchange capacity. 
Soil physical attributes showed higher Ds values at the three studied depths in the soil with Caatinga; the area with onion showed the highest values among the evaluated production systems (Table 3). Lopes et al. (2012) verified higher values of soil density in the surface soil layer of the Caatinga area, which was attributed to the presence of crop residues in this area.

Soil compaction may occur in the area under onion cultivation due to more continuous use and because it is an irrigated crop with a short cycle. Besides, mechanical management practices such as plowing alter the original soil structure (Cortez et al., 2011; Dantas et al., 2012). Thus, systems that favor soil structuring, such as those that increase organic matter contents, should be adopted in areas with degradation signs (Stefanoski et al., 2013; Sales et al., 2016).

All soil uses had ratios of micropores higher to those of macropores at the three depths (Table 3). Despite this, ratios lower than 2:1 were verified in banana and corn cultivations and Caatinga area at depths of $0.00-0.10$ and $0.10-0.20 \mathrm{~m}$, and in banana, cassava, and corn cultivations at a depth of $0.20-0.40 \mathrm{~m}$ (Table 3 ). This result is possibly related to the predominance of fine and very fine sand fractions over the coarser fractions, a striking feature in some sandy soils of the semiarid region (Santos et al., 2012).

The depth of $0.0-0.10 \mathrm{~m}$ showed acidification and loss of exchangeable bases $(\mathrm{K}, \mathrm{Ca}$, and $\mathrm{Mg})$, mainly in corn, cassava, and banana cultivations. The OM contents were lower when compared to the Caatinga regardless of the soil use, while $\mathrm{P}$ contents remained close, except for cassava (Table 3 ).

The depth of $0.10-0.20 \mathrm{~m}$ presented exchangeable base contents close to those observed in the soil under Caatinga, except for $\mathrm{Ca}$ (Table 3). In addition, OM contents were similar to that found in the Caatinga only for onion and banana cultivations. A significant increase in assimilable $\mathrm{P}$ contents was observed in soils cultivated with these crops (Table 3).

The depth of $0.20-0.40 \mathrm{~m}$ had an increase in $\mathrm{K}, \mathrm{Ca}$, and $\mathrm{Mg}$ contents in relation to the Caatinga, with the maintenance of $\mathrm{pH}$ values (Table 3 ). It is probably due to the management used in each crop, with low or without the addition of inputs in corn and cassava cultivations and high addition of manure and nutrients, mainly phosphate, in the areas with onion and banana. These factors, together with the irrigation (surface) and inadequate management may have contributed to nutrient losses due to export and leaching, taking into account the sandy soil texture.

Morais et al. (2014) also observed pH values above neutrality in soils under irrigated banana cultivation and native forest (Caatinga), with low availability of phosphorus and micronutrients under these conditions. These authors also emphasized that the increased $\mathrm{pH}$ in cultivated areas is closely related to the fertilizer hydrolysis process, such as urea, which is widely used in onion cultivation.

Increased $\mathrm{P}$ in cultivated areas may be explained by the residual effect of phosphate fertilizers over the years although its high concentrations in these areas are associated with overestimation of $\mathrm{P}$ availability because this form of $\mathrm{P}$ is not readily available to plants, except for those that acidify their rhizosphere, as reported by Morais et al. (2015). According to these authors, the increased $P$ in depth, especially in surface soil layers (Table 3), can be attributed to the high moisture and descending flow of water, which promote an increase in the diffusion and percolation of $P$.

In general, low $\mathrm{CEC}_{\text {eff }}$ values were observed in the soils due to their sandy constitution and low OM contents (Table 3). According to Santos et al. (2012), it favors strong leaching of elements during rainy seasons, leading to their lower exchangeable contents in the soils. Besides these factors, the use of low-efficiency irrigation systems (furrows and flooding) in the region promotes higher losses of soil elements by their removal.

Soils presented, in general, low to medium contents for exchangeable $\mathrm{Ca}, \mathrm{Mg}$, and $\mathrm{K}$, mainly under cassava and corn cultivations (Table 3 ), as they are areas of family production with a low or no contribution of external inputs. Similarly, assimilable $\mathrm{P}$ contents in areas with cassava and corn were considered low, unlike that observed in the area with onion at a depth of $0.10-0.20 \mathrm{~m}$ and with banana at depths of $0.10-0.20$ and $0.20-0.40 \mathrm{~m}$ (Table 3).

The principal component analysis (PCA) was carried out aiming at evidencing the attributes associated with changes in the areas due to the used agricultural management. Two components were extracted, which accounted for $68.67,77.47$, and $71.58 \%$ of the total variability of the data at depths of $0.00-0.10,0.10-0.20$, and $0.20-0.40 \mathrm{~m}$, respectively (Table 4). 
TABLE 4. Contribution of each principal component and attributes at depths of $0.00-0.10,0.10-0.20$, and $0.20-0.40 \mathrm{~m}$.

\begin{tabular}{|c|c|c|c|c|c|c|}
\hline \multirow{3}{*}{ Attribute } & \multicolumn{4}{|c|}{ Principal component } & & \\
\hline & \multicolumn{2}{|c|}{$0.00-0.10 \mathrm{~m}$} & \multicolumn{2}{|c|}{$0.10-0.20 \mathrm{~m}$} & \multicolumn{2}{|c|}{$0.20-0.40 \mathrm{~m}$} \\
\hline & $\mathrm{PC} 1$ & $\mathrm{PC} 2$ & PC1 & $\mathrm{PC} 2$ & $\mathrm{PC} 1$ & $\mathrm{PC} 2$ \\
\hline Ds & 0.74 & 0.43 & -0.41 & -0.74 & 0.46 & -0.68 \\
\hline $\mathrm{Ma}$ & -0.36 & 0.78 & 0.77 & -0.51 & -0.39 & 0.80 \\
\hline Mi & 0.14 & 0.66 & -0.18 & 0.86 & 0.08 & -0.68 \\
\hline $\mathrm{OM}$ & 0.68 & 0.49 & -0.52 & -0.06 & -0.80 & -0.33 \\
\hline $\mathrm{pH}$ & 0.80 & 0.31 & -0.51 & -0.79 & 0.45 & 0.52 \\
\hline $\mathrm{P}$ & 0.12 & -0.37 & -0.84 & 0.26 & -0.92 & -0.27 \\
\hline $\mathrm{K}$ & 0.89 & -0.13 & -0.79 & -0.14 & -0.42 & 0.73 \\
\hline $\mathrm{Ca}$ & 0.97 & -0.071 & -0.97 & -0.034 & -0.95 & 0.15 \\
\hline $\mathrm{Mg}$ & 0.82 & -0.21 & -0.98 & 0.009 & -0.80 & -0.12 \\
\hline $\mathrm{Na}$ & 0.89 & -0.24 & -0.96 & 0.002 & 0.76 & -0.36 \\
\hline $\mathrm{H}+\mathrm{Al}$ & -0.30 & -0.58 & -0.16 & 0.75 & -0.28 & -0.73 \\
\hline $\mathrm{CEC}_{\text {eff }}$ & 0.96 & -0.009 & -0.97 & -0.015 & -0.93 & 0.20 \\
\hline Eigenvalue & 6.04 & 2.19 & 6.48 & 2.82 & 5.30 & 3.29 \\
\hline Variance (\%) & 50.36 & 18.21 & 54.00 & 23.47 & 44.19 & 27.39 \\
\hline
\end{tabular}

Ds: soil density; Ma: macroporosity; Mi: microporosity; OM: organic matter; P: assimilable phosphorus; Mg: exchangeable magnesium; Ca: exchangeable calcium; $\mathrm{K}=$ exchangeable potassium; $\mathrm{Na}$ : exchangeable sodium; $\mathrm{H}+\mathrm{Al}$ : potential acidity; $\mathrm{CEC}$ eff: effective cation exchange capacity.

The principal component 1 (PC1) is more associated with groups of chemical attributes, while the principal component $2(\mathrm{PC} 2)$ is more related to soil physical attributes when considering the three depths (Table 4). It means that soil chemical characteristics were more changed by the management, being more sensitive and having the possible use as quality indicators. The PC1, generated by soil attributes at a depth of $0.00-0.10 \mathrm{~m}$ (Table 4), explained $50.36 \%$ of the total variance of the studied attributes, being those with the highest load $(\geq 0.65$ in absolute value) an indication soil compaction (Ds), soil reaction $(\mathrm{pH})$, nutrient availability $(\mathrm{OM}, \mathrm{K}, \mathrm{Ca}, \mathrm{Mg}$, $\mathrm{CEC}_{\text {eff }}$ ), and salinization (Na) (Table 4). In other words, these attributes discriminated better the differences between areas.

These results corroborate a discussion of Table 3, which shows that, in general, the management of the Quartzipsamment provided a reduction in its natural density and fertility, as well as a slight increase in the exchangeable sodium $(\mathrm{Na})$ content of onion cultivation. According to Dantas et al. (2012), the decreased soil density (Ds) in uses other than onion cultivation can be attributed to a lower soil disturbance and higher return of residues to the soil.

On the other hand, the high Ds values observed in the Caatinga area indicate an advance of degradation problems. Ursulino \& Moreno (2014) evaluated the physical quality of an Entisol in the semiarid region of northwestern Brazil and found mean Ds values close to $1.50 \mathrm{Mg} \mathrm{m}^{-3}$, which is considered high. This result was attributed to deforestation in the area, which causes pluvial erosion effects, causing surface sealing, which increased soil density. It is similar to that observed in the Caatinga area of the present study (Table 3).

Also, a higher $\mathrm{Na}$ content was observed in the surface soil layer of the area with onion when compared to the Caatinga area, with a mean value of $125 \%$ (Table 3 ). $\mathrm{Na}$ accumulation is mainly related to the management of irrigation water (Morais et al., 2015). Thus, a continuous accumulation should be prevented to avoid affecting the yield of cultivated areas, being required the effective management of the irrigation water depth (Dantas et al., 2012).

Soil porosity (Ma and Mi) and chemical quality were more sensitive in discriminating banana, cassava, and corn uses possibly due to the management systems used in these areas, which contributed to an intermediate change. In this case, the values of fertility-related attributes were usually similar and thus, different from those observed in onion cultivation and Caatinga (Tables 3 and 4).

Therefore, according to the results found in this layer (Tables 3 and 4), soils cultivated with onion and native vegetation (Caatinga) were strongly discriminated by $\mathrm{Ds}, \mathrm{OM}, \mathrm{CEC}_{\text {eff }}, \mathrm{K}, \mathrm{Ca}, \mathrm{Mg}$, and $\mathrm{Na}$ when compared to soils with banana, cassava, and corn. In addition, macroporosity was more sensitive in discriminating soils with cassava and Caatinga, while soil microporosity (Mi) influenced soils cultivated with banana, onion, and corn (Tables 3 and 4).

At a depth of $0.10-0.20 \mathrm{~m}, \mathrm{PC} 1$ explained $54 \%$ of the total variance of the data and attributes related to soil macroporosity $(\mathrm{Ma})$, nutrient availability $(\mathrm{P}, \mathrm{K}, \mathrm{Ca}, \mathrm{Mg}$, and $\left.\mathrm{CEC}_{\text {eff }}\right)$, and accumulation of salts $(\mathrm{Na})$ were more sensitive in distinguishing the areas (Table 4). PC2 explained $23.47 \%$ of the total variance in the data, being composed by indicator variables of compaction (Ds and $\mathrm{Mi})$ and soil reaction ( $\mathrm{pH}$ and $\mathrm{H}+\mathrm{Al})$ (Table 4).

The attributes Ds, Ma, and $\mathrm{pH}$ strongly discriminated soils with cassava and Caatinga, with a higher proportion of macropores in relation to micropores and lower values of $\mathrm{pH}$ and Ds in cassava cultivation, but with opposite results in the Caatinga (Tables 3 and 4). On the other hand, the higher proportion of micropores in relation to macropores discriminated soils with onion, banana, and corn, while $\mathrm{P}, \mathrm{K}, \mathrm{Ca}, \mathrm{Mg}, \mathrm{Na}$, and CEC contents strongly discriminated onion cultivation and moderately discriminated the soil with banana (Tables 3 and 4). 
At a depth of $0.20-0.40 \mathrm{~m}, \mathrm{PC} 1$ explained $44.19 \%$ of the total variance of the data and was composed by the variables $\mathrm{OM}, \mathrm{P}, \mathrm{Ca}, \mathrm{Mg}$, and $\mathrm{CEC}_{\text {eff, while } \mathrm{PC} 2 \text { explained }}$ $27.39 \%$ of the total variance and was composed of physical (Ds, Ma, and Mi) and chemical variables ( $\mathrm{K}$ and $\mathrm{H}+\mathrm{Al}$ ) (Table 4). High P contents were mainly observed in this layer, while $\mathrm{Ca}$ and $\mathrm{Mg}$ discriminated the area with banana and base accumulation, related to an increase in $\mathrm{Ca}$ and $\mathrm{Mg}$ contents, discriminated cassava and corn areas (Table 3).

The variables $\mathrm{Ds}, \mathrm{Mi}$, and $\mathrm{H}+\mathrm{Al}$ were strongly sensitive in discriminating soils cultivated with onion and Caatinga, also moderately influencing banana cultivation (Tables 3 and 4). Ma significantly discriminated the uses of cassava and corn and moderately banana cultivation, which was grouped alone in cluster analysis (Tables 3 and 4).

Caatinga and onion areas presented similarities regarding their physical and chemical attributes (Table 3). These areas had the highest Ds values and higher proportions of micropores in relation to macropores at the three depths, as well as the highest values of $\mathrm{OM}, \mathrm{CEC}_{\text {eff, }}$, and nutrient contents in the surface soil layer, but reducing in depth (Table 3). Corn and cassava areas were usually more homogeneous, mainly due to the lower mean Ds values and low OM values in the first two layers, which may have promoted the lower fertility (Table 3). Finally, in isolation, soil use with banana, mainly in subsurface layers, presented the highest $\mathrm{P}$ and $\mathrm{OM}$ values, which are possibly associated with the higher fertility (Table 3 ).

These results confirmed the importance of the physical attributes $\mathrm{Ds}$, $\mathrm{Ma}$, and $\mathrm{Mi}$ as soil quality indicators of the northeastern semiarid region, as reported by Arcoverde et al. (2015). These authors highlighted Ma as a sensitive attribute for discriminating the physical quality at a depth of $0.00-0.10$ and $0.10-0.20 \mathrm{~m}$, while Ds and Mi were more important at a depth of $0.20-0.40 \mathrm{~m}$, thus being considered good soil quality indicators.

Lopes et al. (2012) observed higher OM values in the surface soil layer of a Caatinga area when compared to an area with melon, which was attributed to the presence of dead coverage in this area as depth decreased. Also, a significant increase in OM was observed at a depth of $0.20-0.40 \mathrm{~m}$ when compared to the soil under Caatinga, which is similar to the result obtained in the area with banana of this study.
The results in the corn and cassava areas, especially in the surface soil layers, are possibly due to the inadequate irrigation management associated with the sandy texture and fertilization, which was insufficient to meet crop demands. Thus, the low values of exchangeable bases are due to the leaching, which promotes the accumulation of these elements at a depth of $0.20-0.40 \mathrm{~m}$, acidifying the surface layers, revealed by very low $\mathrm{pH}$ values. Xavier et al. (2012) observed that the low $\mathrm{pH}$ values in the surface soil layer are due to the low recharge of soluble salts from fertilizer application or even the entry of these ions from irrigation water.

From the confirmation of the soil attributes that promoted differences between areas through the principal component analysis, the hierarchical cluster analysis was performed, according to Ward's method, aiming at classifying the soil attributes and principal components into homogeneous clusters (Freitas et al., 2014). In this sense, the cluster analysis technique for the set of studied variables allowed complementing efficiently the results obtained with the use of the principal component analysis (Figure 1).

With the use of significant attributes in PC1, Ward's method was used with the similarity measure given by the Euclidean distance aiming to group them, defining the cut-off distance equal to $50 \%$ of the maximum Euclidean distance. In this analysis, onion, banana, cassava, corn, and Caatinga areas were grouped according to their degree of similarity, classifying them into homogeneous clusters (Oliveira et al., 2015).

The combined use of physical and chemical attributes at a depth of $0.00-0.10 \mathrm{~m}$ (Figure 1A) allowed the data to be sorted into two clusters: the first one encompassing cassava, corn, and banana areas and the second cluster encompassing the data of Caatinga and onion areas. Production systems grouped into the first cluster are those with the lowest contribution of inputs and those with the highest chemical changes in relation to the Caatinga soil, with reductions in $\mathrm{pH}$ values and exchangeable base contents.

The clustering using the data from a depth of 0.10 $0.20 \mathrm{~m}$ (Figure 1B) provided the formation of two clusters: the first one formed by Caatinga, corn, cassava, and banana areas, and the second one with the onion area. The separation of the onion area from the other production systems is mainly due to differences in $\mathrm{P}$ content observed at this depth. 

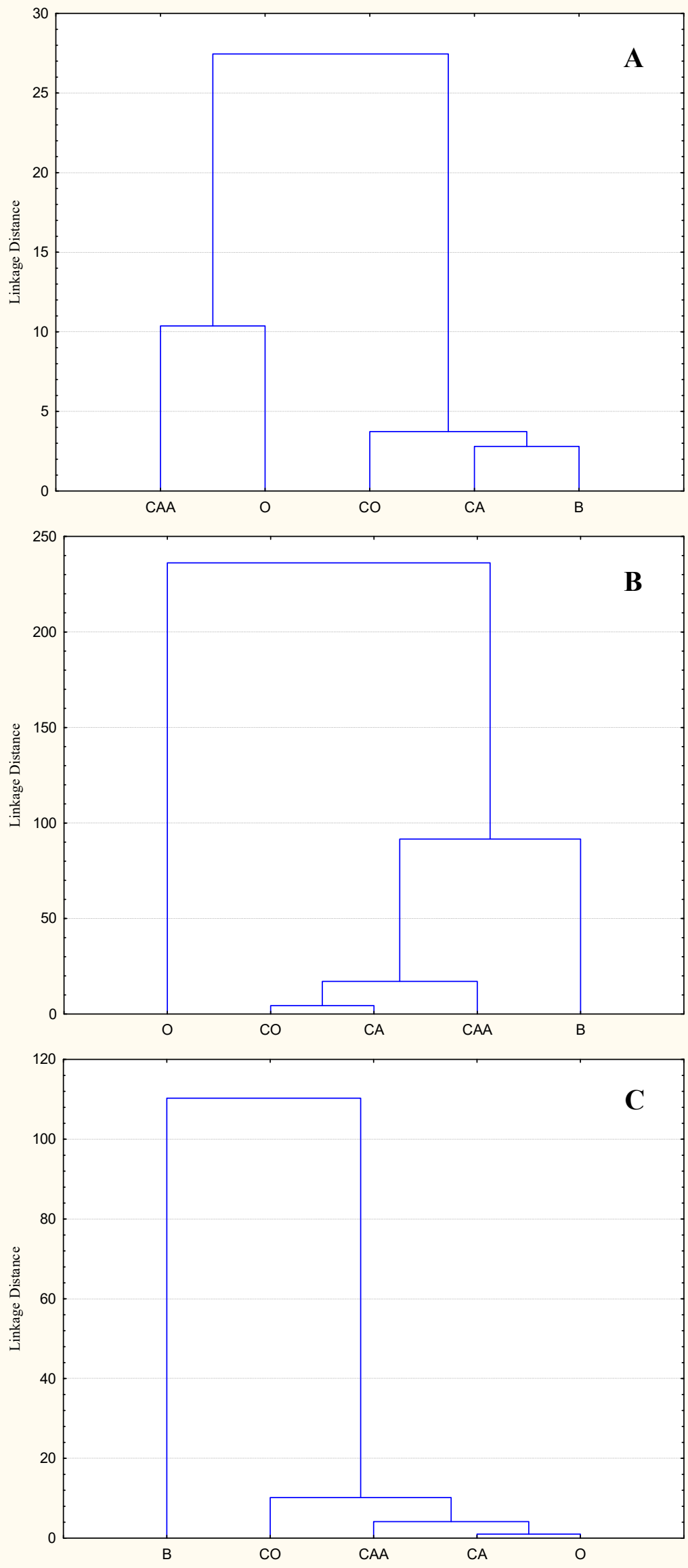

FIGURE 1. Dendrogram resulting from the hierarchical cluster analysis showing the formation of clusters according to chemical and physical attributes. A) depth of $0.00-0.10 \mathrm{~m}$; B) depth of $0.10-0.20 \mathrm{~m}$; C) depth of $0.20-0.40 \mathrm{~m}$. O - onion; B banana; CA - cassava; $\mathrm{CO}$ - corn; CAA - Caatinga. 
The cluster analysis from the data of soil chemical and physical attributes at a depth of $0.20-0.40 \mathrm{~m}$ allowed a clear division into two clusters. The first cluster consisted of the data of the area with banana, while the second cluster was composed of the data of the other areas (Figure $1 \mathrm{C})$. In this case, soil $\mathrm{P}$ content was probably the attribute that differentiated the banana production system, in addition to $\mathrm{Ca}$ and $\mathrm{K}$ contents.

A higher similarity was observed between areas with onion and Caatinga at depths of $0.00-0.10$ and 0.20 $0.40 \mathrm{~m}$, with the smallest changes in soil fertility due to onion management. Areas with corn and cassava cultivation showed similarity at the three depths because the management systems are similar, with no replacement of nutrients removed from the soil by crops, causing acidification in the most superficial layer and base accumulation in the deepest soil layer (Figure 1).

The results of the cluster analysis of the three layers for the analyzed physical and chemical attributes (Figure 1) showed that their changes allowed a marked differentiation of clusters, with clear distinction between the onion cultivation of the other areas at a depth of 0.10 $0.20 \mathrm{~m}$ and the area with banana at a depth of $0.20-0.40 \mathrm{~m}$, suggesting a higher effect of management on the subsurface soil layers.

Thus, PCA and cluster analysis showed clear changes in soil physical and chemical attributes due to the specific management adopted in the studied areas, thus being efficient techniques to study the quality of Quartzipsamments from the identification of indicators sensitive to the management.

In general, the differentiation of the areas according to the management was evident despite being very similar due to the predominance of loamy sandy texture. Thus, areas with cassava and corn cultivation had a higher deficiency and limitation from the point of view of soil fertility in the surface layers when compared to the Caatinga area, although with base accumulation due to leaching in depth. This behavior was related to the management of fertilization carried out in these areas. On the other hand, banana cultivation had an improvement in soil quality in depth as fertility increased probably due to higher $\mathrm{P}, \mathrm{Ca}, \mathrm{Mg}$, and $\mathrm{OM}$ contents, which allowed differentiating this use from the others.

Changes in soil physical attributes and $\mathrm{Na}$ accumulation in the surface layer show the beginning of degradation processes related to soil compaction and salinization, despite the similarity regarding soil quality of Caatinga and onion areas.

\section{CONCLUSIONS}

Principal component analysis and hierarchical cluster techniques allowed the identification of different production systems in subsurface soil layers, suggesting the effect of soil fertility on the differentiation of areas with onion at a depth of $0.10-0.20 \mathrm{~m}$ and banana at a depth of $0.20-0.40 \mathrm{~m}$, as well as the clustering of cassava and corn cultivations at the three studied layers. Therefore, soil fertility is the main responsible for soil quality.

The physical attributes $\mathrm{Ds}$, $\mathrm{Ma}$, and $\mathrm{Mi}$ and $\mathrm{Na}$ content of the surface layer of the area with onion showed a tendency of compaction and salinization. The former variables were also sensitive, together with soil fertility, in differentiating the studied areas.
In general, an improvement in soil quality with agricultural use was observed in depth when compared to the Caatinga.

\section{ACKNOWLEDGMENTS}

To CNPq, Embrapa Semi-Arid, and CHESF for financial support.

\section{REFERENCES}

Arcoverde SNS, Salviano AM, Olszevki N, Melo SB, Cunha TJF, Giongo V, Pereira JS (2015) Qualidade física de solos em uso agrícola na Região Semiárida do Estado da Bahia. Revista Brasileira de Ciência do Solo 39(5):1473-1482.

Burak DL, Passos RR, Andrade FV (2012) Variabilidade espacial de atributos químicos do solo sob cafeeiro Conilon: relação com textura, matéria orgânica e relevo. Bragantia 71(4):538-547.

Corrêa RM, Freire MBG, Ferreira RLC, Silva JAA, Pessoa LGM, Miranda MA, Melo DVM (2010) Atributos físicos de solos sob diferentes usos com irrigação no semiárido de Pernambuco. Revista Brasileira de Engenharia Agrícola e Ambiental 14(4):358-365.

Cortez JW, Alves ADS, Moura MRD, Olszevski N, Nagahama HJ (2011) Atributos físicos do Argissolo amarelo do semiárido nordestino sob sistemas de preparo. Revista Brasileira de Ciência do Solo 35(4):1207-1216.

Dantas JD'arc N, Oliveira TS, Mendonça ES, Assis CP (2012) Qualidade de solo sob diferentes usos e manejos no Perímetro Irrigado Jaguaribe/Apodi, CE. Revista Brasileira de Engenharia Agrícola e Ambiental 16(1):18-26.

Donagema GK, Campos DVB de, Calderano SB, Teixeira WG, Viana JHM (2011) (org). Manual de métodos de análise de solos. Rio de Janeiro, Embrapa Solos, 2 ed. 230p. ( Documentos, 132).

Freitas L, Casagrande JC, Oliveira IA, Júnior PRS, Campo MCC (2014) Análises multivariadas de atributos químicos do solo para caracterização de ambientes. Revista Agro@mbiente On-line 8(2):155-164.

Jacomine PTK (1996) Solos sob caatinga: características e uso agrícola. In: Alvarez VVH, Fontes LEF, Fontes MPF. O solo nos grandes domínios morfoclimaticos do Brasil e o desenvolvimento sustentado. Sociedade Brasileira de Ciência do Solo, Universidade Federal de Viçosa, p 96-111.

Lopes HSS, Medeiros MG, Silva JR, Medeiros Júnior FA, Santos MN, Batista RO (2012) Biomassa microbiana e matéria orgânica em solo de Caatinga, cultivado com melão na Chapada do Apodi, Ceará. Revista Ceres 59(4):565-570.

Morais ERC, Maia EC, Gaudêncio HRSC, Sousa DMM (2015) Indicadores da qualidade química do solo em áreas cultivadas com mamoeiro irrigado. Revista Brasileira de Engenharia Agrícola e Ambiental 19(6):587-591. 
Morais ERC, Oliveira AAS, Maia CE (2014) Qualidade do solo cultivado com banana irrigada e sua relação com áreas de caatinga. Revista Brasileira de Engenharia Agrícola e Ambiental 18(9):887-891.

Mota LHSO, Valladares GS (2011) Vulnerabilidade à degradação dos solos da Bacia do Acaraú, Ceará. Revista Ciência Agronômica 42(1):39-50.

Oliveira IA, Campos MCC, Freitas L, Soares MDR (2015) Caracterização de solos sob diferentes usos na região sul do Amazonas. Acta Amazonica 45(1):1-12.

Pragana RB, Ribeiro MR, Nóbrega JCA, Ribeiro Filho MR, Costa JA (2012) Qualidade física de Latossolos Amarelos sob plantio direto na região do cerrado piauiense. Revista Brasileira de Ciência do Solo 36(5):1591-1600.

Sales LEO, Carneiro MAC, Severiano EC, Oliveira GC, Mozart MF (2010) Qualidade física de Neossolo Quartzarênico submetido a diferentes sistemas de uso agrícola. Ciência e Agrotecnologia 34(3):667-674.

Sales RP, Portugal AF, Moreira JAA, Kondo MK, Pegoraro RF (2016) Revista Ciência Agronômica 47(3):429-438.
Santos JCB, Souza Júnior VS, Corrêa MM, Ribeiro MR, Almeida MC, Borges LEP (2012) Caracterização de Neossolos Regolíticos da região do semiárida do estado de Pernambuco. Revista Brasileira de Ciência do Solo 36(3):683-695.

Stefanoski DC, Santos GG, Marchão RL, Petter FA, Pacheco LP (2013) Uso e manejo do solo e seus impactos sobre a qualidade física. Revista Brasileira de Engenharia Agrícola e Ambiental 17(12):1301-1309.

Stolf R, Thurler AM, Bacchi OOS, Reichardt K (2011) Method to estimate soil macroporosity and microporosity based on sand content and bulk density. Revista Brasileira de Ciência do Solo 35(2):447-459.

Ursulino DMA, Moreno MMT (2014) Avaliação da qualidade de solos através de indicadores físicos e mineralógicos. Revista de Ciências Agrárias 37(2):179-186.

Xavier FAZ, Tavares RC, Gleidson VM, Rodrigues FM, Oliveira TS (2012) Efeitos da irrigação localizada na granulometria e em atributos químicos de um Neossolo Quartzarênico cultivado com coqueiro anão. Revista Ciência Agronômica 43(1):55-63. 